Jusmal lemiah
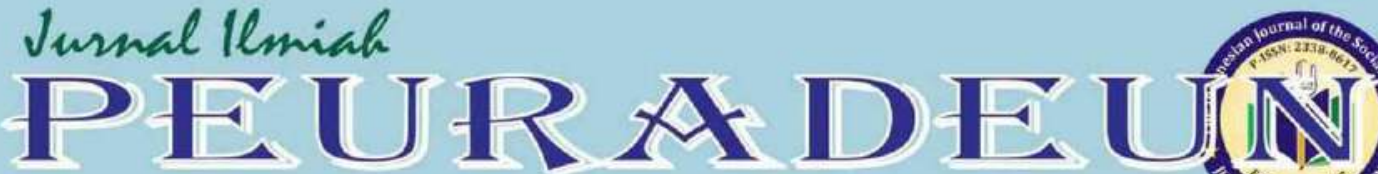

Vol. 8, No. 3, September 2020

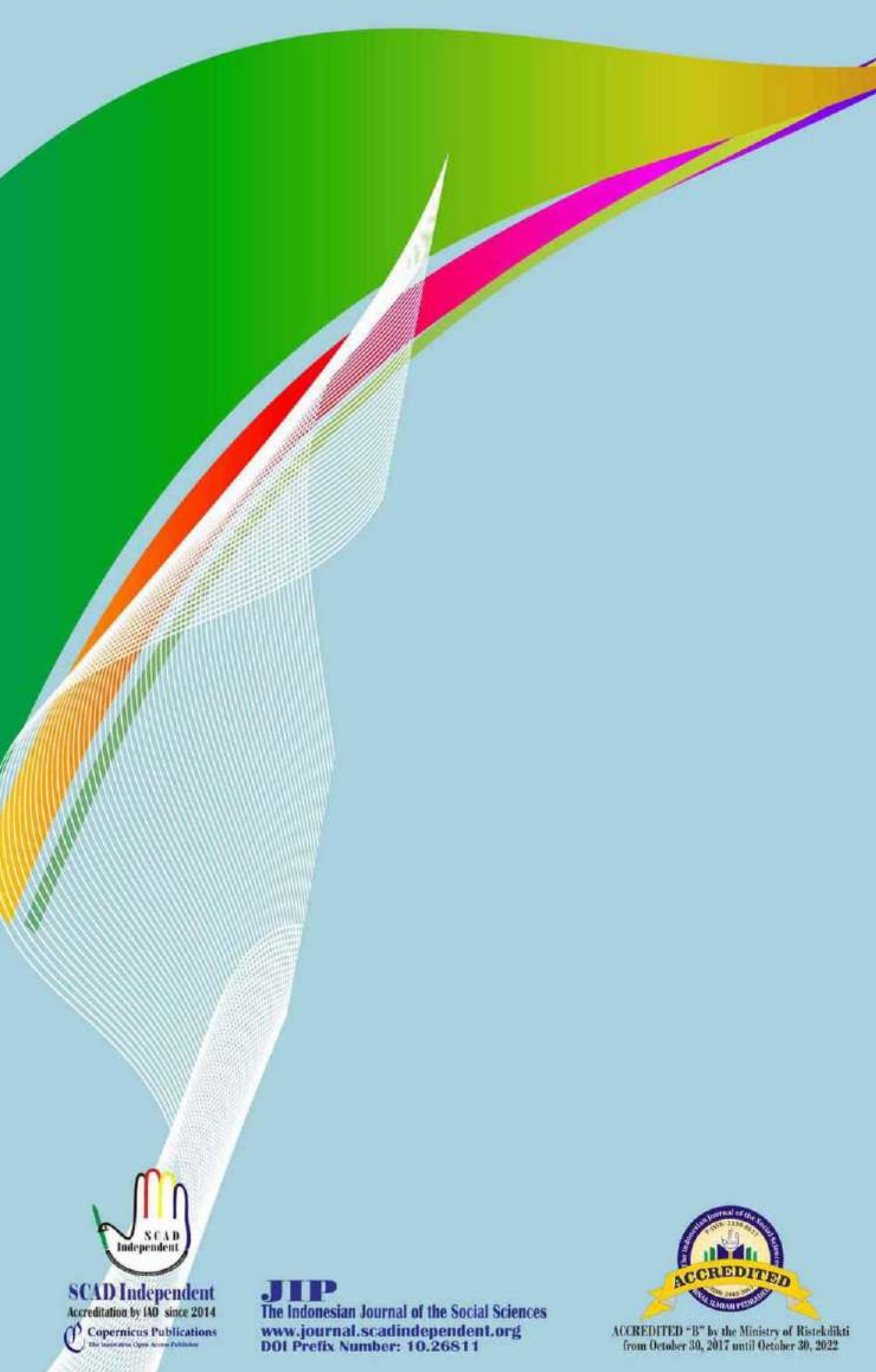

\section{Clarivate Analytics}

Emerging Sources Citation Index Web of Science ${ }^{\mathrm{TM}}$

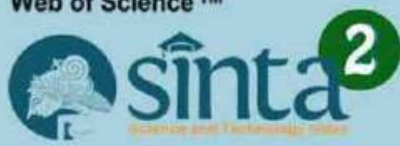

INDEX $\circledast$ COPERNICUS www.journal.scadindependent.org Dot Prefix Number: 10.2681 


\author{
JURNAL ILMIAH PEURADEUN \\ The Indanesian Journal of the Sacial Sciences \\ p-ISSN: 2338-8617/ e-ISSN: 2443-2067
}

www.journal.scadindependent.org

\author{
Vol. 8, No. 3, September 2020
}

Pages: 451-474

\title{
The Development of KKNI-Based Curriculum at the Arabic Language Education Programs in Indonesian Higher Education
}

\author{
Ismail Muhammad ${ }^{1}$ \& Safrina Ariani ${ }^{2}$ \\ ${ }^{1}$ Ar-Raniry State Islamic University, Indonesia \\ 2International Islamic University Malaysia, Malaysia
}

\begin{abstract}
Article in Jurnal Ilmiah Peuradeun
Available at : https://journal.scadindependent.org/index.php/jipeuradeun/article/view/543

DOI $\quad$ : http://dx.doi.org/10.26811/peuradeun.v8i3.543
\end{abstract}

\begin{abstract}
How to Cite this Article
APA : Muhammad, I., \& Ariani, S. (2020). The Development of KKNI-Based Curriculum at the Arabic Language Education Programs in Indonesian Higher Education. Jurnal Ilmiah Peuradeun, 8(3), 451-474. doi:10.26811/ peuradeun.v8i3.543
\end{abstract}

Others Visit : https://journal.scadindependent.org/index.php/jipeuradeun

Jurnal Ilmiah Peuradeun (JIP), the Indonesian Journal of the Social Sciences, is a leading peer-reviewed and openaccess journal, which publishes scholarly work, and specializes in the Social Sciences that emphasize contemporary Asian issues with an interdisciplinary and multidisciplinary approach. JIP is published by SCAD Independent and published 3 times of year (January, May, and September) with p-ISSN: 2338-8617 and e-ISSN: 2443-2067. Jurnal Ilmiah Peuradeun has become a CrossRef Member. Therefore, all articles published will have a unique DOI number. JIP has been accredited by the Ministry of Research Technology and Higher Education Republic of Indonesia (SK Dirjen PRP RistekDikti No. 48a/KPT/2017). This accreditation is valid from October 30, 2017 until October 30, 2022.

JIP published by SCAD Independent. All articles published in this journal are protected by copyright, licensed under a CC-BY-SA or an equivalent license as the optimal license for the publication, distribution, use, and reuse of scholarly works. Any views expressed in this publication are the views of the authors and not of the Editorial Board of JIP or SCAD Independent. JIP or SCAD Independent cannot be held responsible for views, opinions and written statements of authors or researchers published in this journal. The publisher shall not be liable for any loss, actions, claims, proceedings, demand, or costs or damages whatsoever or howsoever caused arising directly or indirectly in connection with or arising out of the use of the research material. Authors alone are responsible for the contents of their articles.

JIP indexed/included in Web of Science, MAS, Index Copernicus International, Sinta, Garuda, Moraref, Scilit, Sherpa/Romeo, Google Scholar, OAJI, PKP, Index, Crossref, BASE, ROAD, GIF, Advanced Science Index, JournalTOCs, ISI, SIS, ESJI, SSRN, ResearchGate, Mendeley and others. 


\title{
THE DEVELOPMENT OF KKNI-BASED CURRICULUM AT THE ARABIC LANGUAGE EDUCATION PROGRAMS IN INDONESIAN HIGHER EDUCATION
}

\author{
Ismail Muhammad ${ }^{1} \&$ Safrina Ariani $^{2}$ \\ ${ }^{1}$ Ar-Raniry State Islamic University, Indonesia \\ 2 International Islamic University Malaysia, Malaysia \\ ${ }^{1}$ Contributor Email: ismara114@gmail.com
}

Received: May 28, 2020

Accepted: Aug 28, 2020

Published: Sep 30, 2020

Article Url: https://journal.scadindependent.org/index.php/jipeuradeun/article/view/543

\begin{abstract}
This study aimed to analyze the pattern of Indonesian National Qualifications Framework-based curriculum development carried out by 5 best Arabic Language Department (PBA) of undergraduate programs -accredited A- in Indonesia. The method used was qualitative research covering document analysis, interviews, and observations that were applied, and followed by data reduction, data display, and conclusion. The results showed that generally, the PBA departments had developed their curriculum by referring to the steps and rules in the KKNI standard. However, the determination of the courses was not carried out in-depth by developing learning outcomes and lesson materials independently, but only by referring to the CPL from the National Standards for Higher Education (SNPT) of the Minister of Education and Culture Regulation (MOEC) No. 49 of 2014, as well as by adjusting the CPL and the lesson materials to existing courses. This was because the PBA study program had difficulties in developing CPL independently. The curriculum structure developed by PBA was based on the serial model curriculum structure where the courses were arranged from the easiest in the first semester to the most difficult one last semester.
\end{abstract}

Keywords: KKNI Curriculum; Arabic Departments; Curriculum Development; CPL 


\section{A. Introduction}

The curriculum is the heart of the teaching and learning program (Habiburrahim, 2017). A good curriculum will enable students to achieve learning outcomes that are important for their development and needs, such as technological development, the need for labor, and the environment. With this in mind, the Indonesian government developed a curriculum based Indonesian National Qualification Framework(KKNIbased curriculum) as stipulated in Indonesian Presidential Regulation no. 8 of 2012 concerning KKNI (Indonesian National Qualifications Framework). In practice, it was then supported by the regulation of the Ministry of Education and Culture (MOEC) no. 73 of 2013 on the implementation of KKNI in higher education. Article 2 of the MOEC regulation stipulated: Section (1) KKNI in higher education is a qualification gradation framework that can juxtapose, equalize, and integrate learning achievements from the path of non-formal education, informal education, and/or work experience into types and levels of higher education. Section (2) the gradation qualification meant in Section (1) intends to facilitate the education of individuals who have work experiences or learning achievements of non-formal or informal education to (a) take formal education to a higher level/level and/or; (b) get recognition of the qualifications of graduates of certain types of education from the Higher Education Institution (MOEC, 2013).

One of the important criteria of the KKNI-based curriculum is that it is developed independently by the study program by referring to the established requirements. The independent curriculum development of the KKNI has become a burden in the realm of applicability because realistically the study program faces various obstacles. Based on personal experiences of the first writer as a Ban-PT assessor since 2014, it shows that from the 27 study programs visited and observed in many parts of Indonesia, only five have developed their curricula based on the KKNI patterns and standards, although they were still not perfect.

This study conducted to analyze the pattern of KKNI-based curriculum development carried out by 5 best PBA departments (Arabic 
Language Department)of undergraduate programs - accredited A- in Indonesia, to unveil problems faced in improving their curriculum and the solutions for the problems, and to put an ideal PBA KKNI-based curriculum based on the experience of those best PBA departments.

\section{B. Method}

This study was carried out in 5 Arabic Departments that are accredited A from Ban-PT by using a qualitative approach to their KKNIbased curriculum and its development patterns.

Data were collected from PBA of UIN Ar-Raniry Banda Aceh, PBA of UIN Syarif Hidayatullah Jakarta, PBA of UIN Maulana Malik Ibrahim, PBA of Jakarta State University, and PBA of Malang State University.

Data collection was carried out through three techniques: document analysis, interviews, and observations, followed by data reduction, data display, and conclusion. The documents of the KKNIbased curriculum from those PBAs analyze their suitability with the Indonesian Presidential Regulation No. 8 of 2012 concerning KKNI (Kerangka Kualifikasi Nasional Indonesia) and the regulation of the Ministry of Education and Culture (MOEC) no. 73 of 2013 on the implementation of KKNI in higher education.

The interviews were done with the head departments of PBAs and their secretary by purposive sampling (Krathwol, 1993).

\section{Result and Discussion}

\section{Patterns of Curriculum Development in the A-accredited PBAs}

In the study conducted on five A-accredited PBAs, researchers found diverse field realities.

a. PBA of UIN Ar-Raniry Banda Aceh

At UIN Ar-Raniry, discussion on the KKNI curriculum was only carried out in 2018. To improve the quality of the KKNI-based curriculum, PBA of UIN Ar-Raniry conducted a curriculum evaluation conducted by a team appointed, which consisted of senior lecturers, head departments, and staff. 
The latest discussion on the pattern of the KKNI-based curriculum was conducted by PBA UIN Ar-Raniry after the appointment of the KKNI-based curriculum drafting team by the Faculty of Tarbiyah and Teacher Training (FTK), through a KKNI-based curriculum workshop for all study programs at FTK on October 20, 2018. Through the workshop, the participant lecturers were again trained to explore the KKNI-based curriculum, with the hope that all study programs will develop the KKNI-based curriculum well.

The curriculum developing teams from each department were tasked to develop the basic curriculum design. Furthermore, the study Programinvited all lecturers in the study program, to get a comprehensive understanding of and explore the steps in the preparation of the KKNI-based curriculum, as well as discuss aspects related to the courses being taught.

As in the KKNI-based curriculum development theory discussed earlier, the initial aspect discussed was the introduction and development of the vision and mission of the PBA of UIN Ar-Raniry, then followed by determining the graduates' profiles. From the graduate profiles, the Graduate Learning Achievement (CPL) was then initiated. The profiles should have distinctions from other universities/institutions PBA's graduates. The distinctions of the graduate profiles of the PBA of UIN Ar-Raniry are to have the ability to be an Educational Research Assistant, to be a Teaching Materials Developer, and to be a Translator/Arabicprenur. These three distinctions have their learning outcomes, which produce optional courses in PBA.

As researchers and participants in the development of the KKNIbased curriculum in PBA of UIN Ar-Raniry, researchers found that the obstacle for KKNI-based curriculum Development was that not all lecturers came to the discussion of the determination of the achievement of learning (CP)and the study materials and its weight, whereas this step is an important part to determine the development of KKNI-based curriculum. The presence of the lecturers was expected to provide information and to assist the team in determining the achievement of learning and study materials and its weight, following the expertise of each lecturer. When the lecturer was absent, the expertise needed in developing the learning outcome and study material was not enough as expected. 
However, for the initial development of the achievement of learning, PBA of UIN Ar-Raniry referred to TheNational Standards for Higher Education (SNPT) instructions. For further development in more detail, the achievement of learning discussion was made during the internal meetings of lecturers who were able to develop the courses. In the discussion about $\mathrm{CP}$ and its relationship with the study materials, PBA UIN Ar-Raniry was constrained by the lack of lecturers' attendance at curriculum discussion meetings. This obstacle was then overcome temporarily by not discussing $\mathrm{CP}$ freely, but rather to adjust the existing $\mathrm{CP}$ and the study material and its weight with the courses that already existed in the previous curriculum structure. This means the KKNI-based curriculum at PBA of UIN Ar-Raniry until August 2019 has not been implemented maximally, but was still in the stage of adjustment and development.

\section{b. PBA of UIN Syarif Hidayatullah Jakarta}

At PBA of UIN Syarif Hidayatullah, the preparation of the KKNI-based curriculum has started since 2015, a year after the issue of MOEC regulation No. 73 of 2013 concerning Learning Achievement following KKNI Level. However, the discussion of the KKNI curriculum at PBA of UIN Syarif Hidayatullah is still being improved. In discussing the KKNI curriculum, PBA UIN Syarif Hidayatullah referred to the six stages of the KKNI curriculum formulated by the higher education, namely: (1) determination of graduate profiles, (2). determination of Graduate Achievement of Learning (CPL); (3) determination of the study material and its weight; (4). determination of courses; (5) determination of credit hours of the courses; (6) curriculum structure preparation; (7) learning process; and (8) assessment(Interview A with Dr. Zainal Muttaqin, M.A.).However, from as of August 2019, the discussion of the KKNI curriculum at PBA of Syarif Hidayatullah had not been carried out thoroughly. For example, the discussion of specialization in the study program has not received an agreement among curriculum discussers (Interview A). Furthermore, Zainal Muttaqin said that the PBA of UIN Syarif Hidayatullah Jakarta did not specifically establish a curriculum discussion unit, and the PBA curriculum discussion team was only formed incidentally, 
according to the needs and discussion of the curriculum itself (also) (Interview A). However, basically, according to him, curriculum evaluation was planned regularly, especially to find aspects of deficiencies that need improvement. In this case, PBA UIN Syarif Hidayatullah was collaborating with an internal expert. The education expert who was also a PBA lecturer at UIN Syarif Hidayatullah, Prof. Dr. Abdul Aziz Fakhrurrozi, MA, acknowledged that PBA often contacted him if help needed in curriculum improvement (Interview B with Prof. Dr. Aziz Fakhrurrozi, MA).

Although it is still in the stage of perfecting the curriculum, PBA of UIN Syarif Hidayatullah has attempted to use the KKNI-based curriculum pattern by following the steps of a systematic discussion. It has set the vision/mission of the study program, and study profile. Also, the discussion on the KKNI-based curriculum has thoroughly addressed the learning outcomes, up to the establishment of the courses which was the object of study by PBA students. However, as stated previously PBA of UIN Syarif Hidayatullah has not yet determined the elective courses based on the study program specialization. From observations on the structure of the curriculum of PBA of UIN Syarif Hidayatullah, researchers did not find many differences between the curriculum currently implemented now and the previous one, except only the content of the courses related to the development of learning media, has begun to lead to the use of multimedia (Interview A).

c. PBA UIN Malik Ibrahim (MALIKI) Malang

PBA of UIN Malik Ibrahim (MALIKI) Malang is considered the best PBA in Indonesia, currently led by Dr. Mamluatul Hasanah, MA. PBA UIN UIN Maliki has begun discussing the KKNI curriculum since the academic year 2015/16(Nurhadi,2017).

Following the SOP outlined by the Quality Assurance Agency (LPM) of UIN MALIKI, the curriculum of a Study Program/Department in UIN MALIKI must be reviewed at least once a year. This activity is carried out regularly in conjunction with the technical guidance program conducted by the study program, which was attended by all human 
resources they have, including 20 tenured PBA lecturers, 1 native speaker from Sudan, 20 tenured faculty lecturers, and 5 adjunct lecturers. An annual event was conducted to discuss all the problems faced by study programs, including curriculum issues. A new curriculum discussion team will be formed, if large curriculum changes are needed, such as curriculum changes to the KKNI format. If the curriculum discussion only concerns a small problem, for example about the follow-up of problems obtained from students, then it is resolved quickly by the head of the department(Interview $\mathrm{C}$ with Dr. Mubaligh).

The KKNI curriculum discussion at PBA of UIN MALIKI was carried out through three stages. The first (pre-compilation) phase includes meeting with invited curriculum experts and friendly meetings with stakeholders and the formation of a formulation team. The second stage (preparation stage) includes the formulation of graduate profiles and Graduate learning achievement, the mapping of the study language, the determination of the courses, credit hours, the distribution of the courses, and the preparation of the Learning Plan (RPS). The third stage (public testing) includes presentations at the Ministry of Religious Affairs (MORA) responsible for Islamic higher education (Diktis), and presentations at university forums (Nurhadi, 2017, 225-226).

Until now the PBA of UIN Maliki has achieved the desired target of the study program, by developing a good KKNI curriculum, which is complemented by specialization in study programs. Currently, PBA of UIN MALIKI has determined four specializations: Learning Arabic for children, Arabic Translation for foreign speakers, Arabic journalism, and Arabic media multi-media expertise. In each of the chosen specialization, students are required to attend the 6 credit hour courses. For this reason, the cumulative number of the courses chosen in PBA of UIN MALIKI is 24 credit hours.

According to the head department of PBA of UIN MALIKI, Dr. Mamluatul Hasanah, M.A., the choice of the specializations was considered as part of the curriculum and the choice of the course was based on the principles of relevance and integration so that graduates can develop professional choices as teachers who master the field of learning Arabic (Interview D with Dr. Mamluatul Hasanah, MA). Furthermore, the head 
department of the PBA explained that the PBA of the UIN MALIKI curriculum component, complemented by the implementation of learning and academic atmosphere that includes the structure and content of the curriculum, graduates' competencies and ethics, degree of integration, local curriculum, and elective courses. The main factor of the success of curriculum discussion at UIN MALIKI was the leadership and lecturers' commitment and the availability of the required documents (Nurhadi: 2017, 225). Mamluatul Hasanah said that the KKNI curriculum at UIN MALIKI was titled KKNI integration and Ulul Albab, the application of which was implemented through the implementation of the mukim program in Ma'had with monitored learning Arabic language (Interview D).

d. PBA Jakarta State University (Universitas Negeri Jakarta/UNJ)

The preparation of the KKNI-based curriculum at the PBA of Jakarta State University (UNJ), has started since 2015. The discussion of the KKNI curriculum began by conducting the KKNI curriculum training by inviting speakers from DIKTI, Dr. Toto Bintoro, MA. In the implementation of the training and the initial introduction of the KKNI curriculum, the lecturers not only learned the curriculum theory but also learned how to develop the KKNI curriculum. In this way, the KKNI curriculum development in PBA UNJ has no significant obstacles, because in general UNJ lecturers understand it. (Interview E with Dr. Nuruddin, M.Pd.).

To facilitate curriculum development at UNJ, LP3M develops curriculum templates consisting of various graduate learning achievement. PBA study program (and also other study programs) only developed graduate learning achievements to strengthen study material that is suitable for the study program's needs. The Graduate learning achievement related to university and faculty level knowledge was developed by his team (Interview E).

e. PBA of Malang State University (Universitas Negeri Malang/UM)

The preparation of the KKNI curriculum at PBA of Malang State University (UM), has started since 2015. The curriculum development plan at 
PBA of UM was carried out by incidental planning, or if needed. This means that curriculum improvement was not carried out with regular plans, but only done if there are new rules, or there are reports of the need for improvement (Interview F withDr. Hanik Mahliatussikah, M.Hum.). As for the curriculum development of KKNI, PBA of UM did it by referring to the rules with clear stages, including: (1) Graduation Profile Determination, (2) Determination of Graduate Learning Achievement (CPL), (3) Determination of Lesson Materials, (4) Determination of the courses, (5) Determination of credit points amount of the courses, (6) Curriculum Structure Preparation, (7) Learning process, (8) Assessment, (9) Preparation of Semester Learning Plans issued by DIKTI.

The head of PBA of UM, Dr. Hanik Mahliatussikah, M.Hum., stressed that PBA did not particularly discuss the courses specified in the discussion of the KKNI-based curriculum, because the existing curriculum structure presentation, according to their internal experts, was considered still good to achieve CPL of PBA. For this reason, PBA of UM only tried to adapt the existing courses to the KKNI-based curriculum format, and only prepared the courses specialization package as a special distinction of PBA of UM (interview F).

Practically, according to Hanik, curriculum development at PBA $\mathrm{UM}$ was not a complicated matter, because they have the supports of many professors in the field of curriculum and Arabic Language, namely Prof. Muhammad Ainin, Prof. Imam Asrari, Prof. Muhaiban, and Indonesian Arabic expert Prof. Dr. Ahmad Fuad Efendi. They are the leaders of the Arabic Teacher and Lecturer Association (IMLA) Indonesia who became the guiding Study Program of PBA and PBSA throughout Indonesia (Interview F).

The PBA curriculum at UM was arranged by dividing the courses into several groups, which produce courses/ groups. The courses group can be seen in the following table:

Table 1 The Division of Courses at PBA of UM

\begin{tabular}{ccc}
\hline No. & Courses Classification & Credits \\
\hline 1. & Personality development courses & 8 \\
2. & Sciences and Skills & 12 \\
\hline
\end{tabular}




\begin{tabular}{ccc}
\hline No. & Courses Classification & Credits \\
\hline 3. & Work Skills & 117 \\
4. & Work Behaviors & 6 \\
5. & Social Life & 8 \\
& Total & $\mathbf{1 5 1}$ \\
\hline
\end{tabular}

The expertise package is another designation of specialization package which is a distinction of Study Program developed specifically by PBA of UM. This expertise package is included as part of the Work Skills courses. This package is classified into several forms: (a) Translation, (b) Islamic Education, (c) Calligraphy, (d) Arabic for Children (Al-Arabiya Li AlAthfal), (e) Computers and the Internet, (f) courses for special purposes. In each specialization package, there are 12 credits hour courses that must be chosen by students. They are required to choose one package consistently and may not choose the courses outside the chosen package. (Interview F).

From the discussion above, it shows that all PBAs that are the subject of this study have tried to develop the KKNI-based curriculum following the rules/instructions. However, the curriculum discussion in those 5 PBA departments has not reached the perfect stage as expected. This fact gives an illustration that if the PBA Study Program excels, the KKNI curriculum development is not yet perfect, then what about other PBA Study Programs in Indonesia. From this fact, it can be seen that, if the government wants the KKNI curriculum to be arranged perfectly and can be applied properly, the government still needs to pay great attention to fostering the study programs and universities in developing the KKNIbased curriculum. Such attention can be in the form of continuous coaching, as well as giving rewards to the study programs that have developed the KKNI-based curriculum perfectly.

\section{Problems encountered by the A Accredited PBAs in the Development of KKNI-Based Curriculumand Solutions for the Problems}

In general, there were several obstacles in the preparation and review of the KKNI-based curriculum conducted at PBAs.

The first problem was that all university lecturers and administrators understood the importance of the curriculum, and had 
already been convinced that the existing curriculum had adequate quality for the development of a field of science. In such a situation, the concept of the KKNI-based curriculum then emerged. Because it is still new, this concept is not yet known in depth. So, to learn it, the KKNI-based curriculum workshop was held. Ironically, most lecturers and leaders did not have time to attend those events, because they had a lot of work, as happened at UIN Ar-Raniry Banda Aceh. However, this obstacle can be overcome by the commitment of all the Islamic higher education (IHE) leaders and lecturers to review the curriculum again as needed. Dr. Nuruddin, M.Pd, the head of the PBA of UNJ, viewed that the leadership's attention plays a positive factor for curriculum improvement (Interview E). In this aspect, all the PBAs investigated in this study took that benefit, because they are under qualified higher education. For instance, when organizing the KKNI-based curriculum workshop, UM Malang did not need to invite external resources persons, because they have KKNI-based curriculum experts. On the other hand, for higher education with internal experts in the KKNI-based curriculum, PBAs had sufficient funds to hold workshops by inviting external speakers.

The second obstacle was the completeness of the discussion on Graduate Learning Achievement(CPL). The CPL discussion should have involved all lecturers who teach the courses in the study program because only those who understand the depth and weight of the study materials are needed for the development of the courses. In the CPL discussion meeting at PBA UIN Ar-Raniry, of the 32 invited lecturers, only five lecturers met. For this reason, PBA was forced to hold repeated meetings to obtain complete CPL. As a solution to this problem, it is necessary to increase awareness and motivation for lecturers on the importance of CPL in curriculum development. And it is expected that the lecturers have a sense of need to engage in the preparation.

However, to develop CPL in general, PBA can be assisted by IMLA (Ittihad Mudarrisi al-Lughah al-Arabiyah/Arabic Teacher and Lecturer Association) Indonesia, which has developed a general CPL template and structured as the PBA curriculum standards in Indonesia. However, the 
results of the IMLA discussions are still limited and general. As a complement, all PBAs must of course develop CPL characterized by certain university PBAs, as a distinction of a university. For the development of CPL which becomes the distinction of PBA, it can be learned from the pattern of developing the course specialization packages in PBA of Malang State University.

The third obstacle faced was the formulation of the KKNI curriculum requires many stages and consumes a lot of time and energy. Therefore, the developers must have many opportunities to complete the curriculum. In addition to discussing the curriculum, it also deals with many rules about the KKNI-based curriculum, such as Presidential Decree, SNPT regulation, and other rules (Nurhadi: 2017, 226). The KKNIbased curriculum is arranged by synchronization between various existing rules. Hence, it is necessary to understand all the rules that can be applied in principle in the preparation of the curriculum.

Another problem faced in connection with the KKNI-based curriculum was the issue of specialization development. PBA managers may use references found in the comparative studies on developing specialization packages, but if they apply it by following Study Program at other universities, they will be constrained by the lack of teaching staff in certain specialization areas. The result is the difficulty of developing the characteristics of the Study Program in the form of specialization. As a solution to this problem, the study program must recruit special lecturers, or invite special lecturers to support the desired courses. This accordingly requires Study Programs to provide more funds.

\section{KKNI-based Curriculum Format and Its Structure based on the Experience of 5 Best PBA Departments}

The curriculum structure is a pattern and arrangement of subjects that must be taken by students while studying a program. From the results of the discussion about the curriculum on the subject of research was obtained several facts. KKNI Structure in PBA UIN Ar-Raniry develops curriculum using serial model curriculum structure, where 
several MKs are developed in the form of serials, for example, Muthalaah I to IV, Muhadatsah I to IV, Insyak I to IV, Nahwu I to IV, Sharaf I to IV. Besides, there are several prerequisites of the courses, such as the Learning Method, Learning Media, Learning Planning, which are the prerequisites of the courses before the implementation of Teaching Practice (PPL), and the Learning Method is a prerequisite for writing the Final Project. The results of these discussions then resulted in a distributed curriculum structure in eight semesters as shown in the table:

Table 2 Curriculum Structure of PBA UIN Ar-Raniry Banda Aceh

\begin{tabular}{ccr}
\hline No. & Courses & Credit \\
1 & Semester I & 2 \\
2 & Pancasila dan Kewarganegaraan & 2 \\
3 & Bahasa Inggris & 2 \\
4 & Matematika Dasar & 2 \\
5 & Bahasa Arab & 2 \\
6 & Ulumul Quran dan Hadits & 2 \\
7 & Istima' I & 2 \\
8 & Muhadatsah I & 2 \\
9 & Nahwu I & 2 \\
10 & Sharaf I & 2 \\
& Muthalaah I & 20 \\
1 & & 2 \\
2 & Total & 2 \\
3 & Semester II & 2 \\
4 & Bahasa Indonesia & 2 \\
5 & Fikh/Ushul Fikih & 2 \\
6 & Filsafat Umum & 2 \\
7 & Ilmu Pendidikan & 2 \\
8 & Istima' II & 2 \\
9 & Muhadatsah II & 2 \\
10 & Nahwu II & 2 \\
11 & Sharaf II & 2
\end{tabular}

Semester III

Total 22

Optional Course choose one

(2) 


\begin{tabular}{ccc}
\hline No. & Courses & Credit hour \\
\hline 2 & Studi Syariat Islam & 2 \\
3 & Psikologi Pendidikan & 2 \\
4 & Manajemen Pendidikan & 2 \\
5 & Filsafat Ilmu & 2 \\
6 & Metode Pembelajaran BA I & 2 \\
7 & Multi-Media PBA & 3 \\
8 & Muhadatsah III & 2 \\
9 & Nahwu III & 2 \\
10 & Sharaf III & 2 \\
11 & Muthalaah III & 2 \\
12 & Insyak II & 2 \\
\end{tabular}

\section{Semester IV}

Total 24

$\begin{array}{cc}1 & \text { MSI } \\ 2 & \text { Statistik Pendidikan } \\ 3 & \text { Filsafat Pendidikan } \\ 4 & \text { Metode Pembelajaran BA II } \\ 5 & \text { Pengemb. Kurikulum Bahasa Arab } \\ 6 & \text { Muhadatsah IV } \\ 7 & \text { Nahwu IV } \\ 8 & \text { Muthalaah IV } \\ 9 & \text { Insyak III } \\ 10 & \text { Balaghah I } \\ 11 & \text { Bahasa Arab Untuk Media Massa } \\ 12 & \text { Bahasa Arab Haji dan Umrah } \\ & \text { Qawaid Tarjamah }\end{array}$

\section{Semester V}

$$
\text { Metode Penelitian Pendidikan }
$$

Total

Optional course, choose one (2)

$$
2
$$

\section{4}

\section{3}

2

3

2

2

Optional course, choose one (2) Pemb. Bahan ajar Bahasa Arab Magang I 2 1 3 1 2

Total 23

\section{Semester VI}


Ismail Muhammad \& Safrina Ariani

\begin{tabular}{|c|c|c|}
\hline No. & Courses & Credit hour \\
\hline 2 & Microteaching & 2 \\
\hline 3 & Metode Penelt Bahasa Arab & 2 \\
\hline 4 & Ilmu Lughah & 2 \\
\hline 5 & Balaghah III & 2 \\
\hline 6 & Tarikh Adab wa al-Nushus & 2 \\
\hline \multirow[t]{3}{*}{7} & $\begin{array}{l}\text { Tarjamah Arab - Indonesia } \\
\text { Edupreuneur Media Elektronika PBA }\end{array}$ & $\begin{array}{l}\text { Optional course, } \\
\text { choose one (2) }\end{array}$ \\
\hline & Total & 13 \\
\hline & Semester VII & \\
\hline 1 & Fiqh Lugha & 2 \\
\hline 2 & Balaghat al-Quran & 2 \\
\hline \multirow[t]{3}{*}{3} & $\begin{array}{c}\text { Pemanfaatan Tekn. Pembelajaran } \\
\text { Edupreuneur Media Cetak PBA }\end{array}$ & $\begin{array}{l}\text { Optional course, } \\
\text { choose one (2) }\end{array}$ \\
\hline & Total & 6 \\
\hline & Semester VII & \\
\hline 1 & PРКPM & 8 \\
\hline \multirow[t]{2}{*}{2} & Skripsi & 4 \\
\hline & Total & 12 \\
\hline
\end{tabular}

PBA UIN Syarif Hidayatullah also developed the curriculum, using the serial structure format as used in the PBA of UIN Ar-Raniry. In the KKNI curriculum developed by PBA UIN Syarif Hidayatullah, various courses accumulated as many as 154 credit points as seen in table 3 .

Table 3 Curriculum Structure of PBA UIN Syarif HidayatullahJakarta

\begin{tabular}{ccc}
\hline No & Courses & Credit hour \\
\hline 1 & Semester I & \\
2 & Studi Islam & 4 \\
3 & Pancasila & 2 \\
4 & Bahasa Indonesia & 3 \\
5 & Bahasa Inggris & 3 \\
6 & Praktikum Qiraah & 2 \\
7 & Muhadatsah 1 & 2 \\
8 & Sharaf 1 & 2 \\
9 & Nahwu 1 & 2 \\
10 & Qiroah 1 & 2 \\
& Istima' 1 & 2 \\
1 & Temester II & Total \\
2 & Ilmu Pendidikan Islam & 2 \\
& &
\end{tabular}




\begin{tabular}{|c|c|c|}
\hline No & Courses & Credit hour \\
\hline 3 & Pendidikan Akhlak & 3 \\
\hline 4 & Praktikum Ibadah & 2 \\
\hline 5 & Ilm Ashwat & 2 \\
\hline 6 & Muhadatsah 2 & 2 \\
\hline 7 & Istima' 2 & 2 \\
\hline 8 & Nahwu 2 & 2 \\
\hline 9 & Qira'ah 2 & 2 \\
\hline \multirow[t]{3}{*}{10} & Sharaf 2 & 2 \\
\hline & \multirow{2}{*}{\multicolumn{2}{|c|}{ Semester III }} \\
\hline & & \\
\hline 1 & & \\
\hline 2 & Muhadatsah 3 & 2 \\
\hline 3 & Balaghah 1 & 2 \\
\hline 4 & Insya' 1 & 2 \\
\hline 5 & Nahwu 3 & 2 \\
\hline 6 & Ilm al-Lughah al-Am & 2 \\
\hline 7 & Media dan Teknologi Pembelajaran BA & 3 \\
\hline 8 & Qiroah 3 & 2 \\
\hline 9 & Filsafat dan Ilmu Pendidikan & 2 \\
\hline 10 & Khat Arabi & 2 \\
\hline \multirow[t]{3}{*}{11} & Psikologi Pendidikan & 3 \\
\hline & Total & 24 \\
\hline & \multicolumn{2}{|l|}{ Semester IV } \\
\hline 1 & Balaghah 2 & 2 \\
\hline 2 & Evaluasi Pembelajaran BA 1 & 2 \\
\hline 3 & Tarjamah 2 & 2 \\
\hline 4 & Insya' 2 & 2 \\
\hline 5 & Metode Khusus Pembelajaran BA 1 & 2 \\
\hline 6 & Ilmu Lughah an-Nafsi & 2 \\
\hline 7 & Qira'ah 4 & 2 \\
\hline 8 & Nahwu 4 & 2 \\
\hline 9 & Al-Lahajat al-Arabiyyah & 2 \\
\hline 10 & Kurikulum dan Pembelajaran & 2 \\
\hline \multirow[t]{3}{*}{11} & Tadribat Lughawiyyah 1 & 2 \\
\hline & Total & 22 \\
\hline & \multicolumn{2}{|l|}{ Semester V } \\
\hline 1 & Metode Khusus Pembelajaran BA 2 & 2 \\
\hline 2 & Insya' 3 & 2 \\
\hline 3 & Balaghah 3 & 2 \\
\hline 4 & Evaluasi Pembelajaran Bahasa Arab 2 & 2 \\
\hline 5 & Fiqh Lughah 1 & 2 \\
\hline 6 & Telaah Kurikulum dan Buku Teks BA 1 & 2 \\
\hline 7 & Metode Penelitian Kependidikan & 2 \\
\hline
\end{tabular}


Ismail Muhammad \& Safrina Ariani

\begin{tabular}{|c|c|c|}
\hline No & Courses & Credit hour \\
\hline 8 & Perencanaan Pembelajaran BA & 2 \\
\hline 9 & Tadribat Lughawiyah 2 & 2 \\
\hline 10 & Ilmu Lughah at-Tatbiqi & 2 \\
\hline \multirow[t]{3}{*}{11} & Metode Khusus Pembelajaran BA 2 & 2 \\
\hline & Total & 24 \\
\hline & \multicolumn{2}{|c|}{ Semester VI } \\
\hline 1 & Fiqih Lughah 2 & 2 \\
\hline 2 & Tarikh al-'Ulum al-'Arabiyyah & 2 \\
\hline 3 & Penelitian Tindakan Kelas (PTK) & 2 \\
\hline 4 & Statistika Pendidikan & 2 \\
\hline 5 & Telaah Kurikulum dan Buku Teks BA 2 & 2 \\
\hline 6 & Metode Penelitian Bahasa & 3 \\
\hline 7 & Strategi Pembelajaran BA & 3 \\
\hline 8 & Ilmu al-Dalalah wa al-Ma'ajim & 2 \\
\hline \multirow[t]{3}{*}{9} & Kepramukaan & 2 \\
\hline & Total & 20 \\
\hline & \multicolumn{2}{|c|}{ Semester VII } \\
\hline 1 & Pengajaran Mikro & 3 \\
\hline \multirow[t]{3}{*}{2} & Nadwah al-Bahts & 2 \\
\hline & Total & 5 \\
\hline & emester VIII & \\
\hline 1 & Praktek Kependidikan & 4 \\
\hline \multirow[t]{2}{*}{2} & Skripsi & 6 \\
\hline & Total & 10 \\
\hline
\end{tabular}

The leaders and lecturers of PBA of UNJ also agreed to use the serial curriculum format. This can be observed, for example, from the design of the courses in the curriculum, especially for the skills courses are in the form of a serial. The examples are Muhadatsah I - IV, Nahwu I - VI, etc. More clearly, the curriculum structure used in PBA of UNJ is presented in Appendix 1, which is quoted from the manual issued by the Faculty of Languages and Literature of UNJ.

The curriculum structure of the PBA of UM was broken down into the courses per semester by also using a serial model. Examples of the courses in the curriculum also use the courses with a serial number, as in other PBAs.

In addition to the courses presented in the curriculum structure above, what was special about PBA of UM was that there were many 
specialization packages, which can be completely interpreted in the following table:

Table 4 The Course Structure for Specialization Package of PBA UM

\begin{tabular}{clc}
\hline No & Translation Package Course & Credits \\
\hline 1 & Translation Technique & 2 \\
2 & Translation Training & 4 \\
3 & Final Project Translation & 4 \\
4 & Translation Entrepreneurship & 2 \\
& Total & $\mathbf{2 1}$ \\
\hline
\end{tabular}

The structure of the PBA curriculum at UM complemented by the courses package specialization structure seems to have different characteristics compared to other PBA curriculum structures in Indonesia. Good characteristics can be seen from the existence of diverse specialization courses that consist of various courses of skills. The choice of the courses can provide additional skills and become an excellent distinction for the students themselves. This model can be an option for PBAs in developing the KKNI curriculum. But it is highly challenging for PBA when developing a curriculum with a variety of packages like this because it must provide sufficient teaching staff. As an alternative, PBA can develop a specialization program in a limited way, for example, only two specializations.

From the description presented above, it can be understood that all PBAs use a serial model structure. This happened because of the many MKs presented in the PBA in the form of MK pre-requisite and graded with the same name, which was then given their respective serial numbers. This is understandable because the curriculum results of the discussion of language study programs are filled with skills courses that are divided into four skills: listening skills, reading skills, speaking skills, and writing skills. Besides, there are also multilevel courses in language science, but different from the content aspects namely Nahwu, Sharaf, and Translating. All of these skills and knowledge are basic knowledge for language students that need to be mastered.

Following Yose Rizal, the curriculum structure of the serial model was a curriculum model in which the preparation of courses was 
conducted from the most basic to the final semester. Each subject is interconnected as indicated by the presence of prerequisite courses (Yose Rizal, 2015, 20). The positive value of this serial model is, if students can complete the MK series well, students after attending lectures will have comprehensive knowledge.

On the other hand, the problem faced in the preparation of the courses based on the serial model exists. If a student fails in a previous serial course, he cannot continue the advanced courses, which results in a slowdown in completing a particular course. Besides, students also cannot take the following courses in the semesters for the course series, because they have not completed the previous courses. Another problem is that if lecturers between the courses continue to not communicate with each other, often the continuation of lectures does not provide students with comprehensive skills.

In PBA, the curriculum structure of this series is seen in the sequencing of the courses which (sometimes) is given a number, for example, Muhadatsah I, Muhadatsah II, Muthalaah I, Muthalaah II, Nahwu I, Nahwu II, etc. It is also seen in the courses which are not numbered but must be sequential, for example, MK teaching theory, must take precedence before taking Teaching Practicum, Research must be taken before Thesis Writing, and so on.

Looking at all the curricula developed in the highly accredited PBA program, it is obvious that the general curriculum structure resembles or is very close to the structure in the structure table developed by IMLA as shown in the following table:

Table 5 The Structure of PBA Curriculum as Results of IMLA Discussion

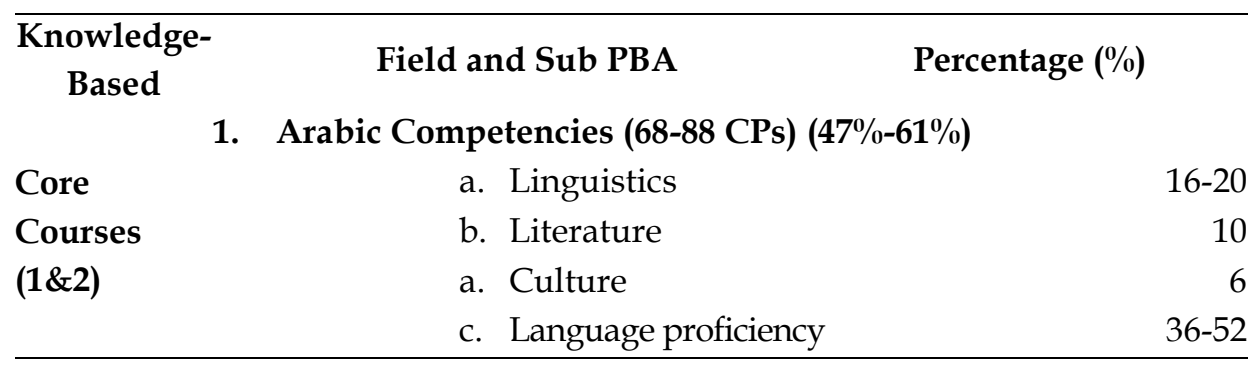




\begin{tabular}{lll}
\hline $\begin{array}{c}\text { Knowledge- } \\
\text { Based }\end{array}$ & Field and Sub PBA & Percentage (\%) \\
\hline
\end{tabular}

2. Profesional Competencies (34-42 CPs) (24\%-29\%)
a. Basics of professionalism (education)
b. Teaching
c. Research and thesis

3. Nationalism (8 CPs) ${ }^{* *}(6 \%)$

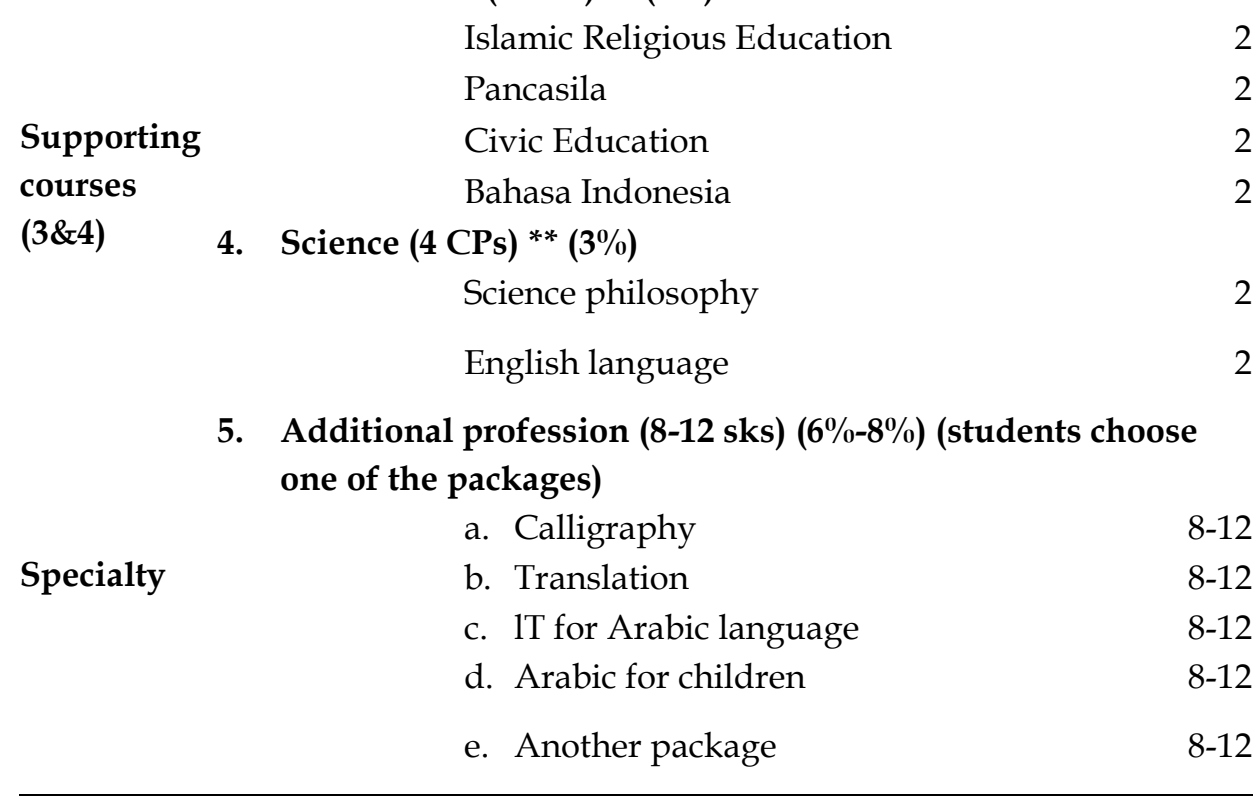

Curriculum structure with the courses offered and the number of credits later became a reference for IMLA to develop a standard guideline for KKNI-based curriculum development in PBA departments. This structure is considered very good, and if implemented well, it will enable graduates to achieve the desired CPL targets. The curriculum structure per semester of the research subject can be observed in the appendix of this study, which is presented in the form of courses to be completed by students each semester.

However, viewed from the aspect of the credit points, the PBA has variations. In the PBA at UIN Ar-Raniry, students must complete 148 credits, UIN Syarif Hidayatullah 154 credits, UIN Malang 148 credits, UNJ 
148 credits, and UM 146 credits. It can be seen that, in general, the number of credits to be completed by students of BA programs in PBA ranges from 146 to 154 credits. This amount is considered ideal and is still within the range of capabilities and time provided. Viewed from the management aspect, this amount can still be managed well.

\section{Conclusion}

The KKNI curriculum development rules have established the stages of curriculum development, including: (1) Graduation Profile Determination, (2) Determination of Graduate Learning Achievement (CPL), (3) Determination of lesson materials, (4) Determination of Subjects, (5) Determination of credit point amount of the courses, (6) Curriculum Structure Preparation, (7) Learning process, (8). Assessment, and (9) Preparation of Semester Learning Plans. In general, the PBA investigated in this study develops the curriculum by following the above steps. However, the determination of the courses was not carried out by developing CPL and lesson materials freely, but rather using CPL that was already in the National Higher Education Standards (SNPT) regulated in MOEC Regulation No. 49 of 2014 and adjusting CPL and the lesson materials with the existing courses. The development of an independent CPL was only carried out for the courses of the specialization, which was adjusted to the local situation and condition of the study program.

In developing the KKNI curriculum, PBA dealt with several obstacles. Firstly, because it was still new, this concept was not yet deeply understood by PBA lecturers and managers. So, a KKNI curriculum workshop was needed. Secondly, the discussion of CPL should involve all lecturers who support the courses in the study program, because they understand the depth and breadth of the lesson materials in developing the courses. However, the CPL discussion meeting was constrained because most of the lecturers did not come to the meeting. As such, the development of CPL independently is difficult to do. Third, the formulation of the KKNI curriculum requires many stages and consumes a lot of time and energy. Accordingly, it needs many opportunities for the developers to do the curriculum discussions, and deal with many rules about the KKNI 
curriculum, such as Presidential Decree, SNPT, and other rules. Fourth, in developing specialization, PBA was constrained by the lack of human resources, making it difficult to develop specialization as needed.

The curriculum structure developed by PBA excelled is the curriculum structure of the serial model, where the courses according to this model, the preparation of courses was conducted from the most basic to the final semester. Each subject was interconnected as indicated by the presence of prerequisite courses. The structure of the serial curriculum is seen in the sequencing of the courses which (sometimes) is numbered, for example, Muhadatsah I, Muhadatsah II, Muthalaah I, Muthalaah II, Nahwu I, Nahwu II, etc. The positive value of this serial model is, if students can complete the course series well, they will have comprehensive knowledge.

\section{Bibliography}

Ahmad (1998). Pengembangan Kurikulum. Bandung: PustakaSetia.

Al-Syaibany, Omar Muhammad al-Toumy. (1979). Falsafah Pendidikan Islam. Jakarta: Bulan Bintang.

Arikunto, Suharsimi. (2002). Prosedur Penelitian: Suatu Pendekatan Praktek. Jakarta: Rineka Cipta.

Arsyad, Azhar. (2004). Bahasa Arab dan Metode Pengajarannya, Beberapa Pokok Pikiran, Yogyakarta: PustakaPelajar.

Casmini. (2014). Evaluasi Dan Peninjauan Kurikulum Berbasis KKNI. Jurnal Hisbah 11 (1), 125-144. doi: https:/ /doi.org/10.14421/hisbah.2014.11107

Creswell, JohnW. (2010). Research Design, Pendekatan Kualitatif, Kuantitatif dan Mixed Terj. Ahmad Fawaid. Jakarta:Pustaka Pelajar.

Derajat, Anna Zakiyyah. Penerapan Kurikulum Berbasis KKNI di Perguruan Tinggi. https://geotimes.co.id/opini/penerapankurikulum-berbasis-kkni-di-perguruan-tinggi/

Doll, Ronald C. (1977). Curriculum Improvement, Decision Making and Process. Boston:Allyn \& Bacon, Inc.

Echols, John M. And Hassan Shadily. (2000). Kamus Inggris Indonesia. Jakarta: Gramedia. 
Gove, Philip Babcock (Ed.) (1966). Webster's Third New International Dictionary. Massa chusetts: G \& C Merriam Company, Publishers Spring field.

Habiburrahim, H. (2017). Developing an English Education Department Curriculum. Jurnal Ilmiah Peuradeun, 5(1), 1-14. doi:10.26811/peuradeun.v5i1.114

Hamalik, Oemar.(2005). Kurikulum dan Pembelajaran. Jakarta: Bumi Aksara. Handāmi, Yahya dan Jābir Abdul Hamīd Jābir. (1987). Al-Manhaj, Asāsuhā, Takhtituhā, Taqwìmuhā. Kairo: Dār al-Nahdhahal-Arabīah.

Ibnu Mandhūr. (2003). Lisānul'Arab.Kairo: Dār al-Hadīs. JuzVII.

Jackson, Philip W. (1992). Conseptions of Curriculum and Curriculum Specialists. In Handbook of Research on Curriculum. NewYork: Simon \& Schuster Macmillan.

Jono, Ali Akbar. (2016). Studi Implementasi Kurikulum Berbasis KKNI Pada Program Studi Pendidikan Bahasa Inggris di LPTK Se-Kota Bengkulu. Jurnal Manhaj4 (1), 57-68. Doi: 10.1161/mhj.v4i1.148

Krathwohl, D. R. (1993). Methods of Educational and Social Science Research.New York: Longman.

Listrianti, F., \& Mundiri, A. (2020). Transformation of Curriculum Development Based on Nationality-Oriented. Jurnal Ilmiah Peuradeun, 8(1), 37-52. doi:10.26811/peuradeun.v8i1.380

Majid, Abdul. (2005). Perencanaan Pembelajaran, Mengembangkan Standar Kompetensi Guru. Bandung: Rosdakarya.

Maleong, LexiJ. (2001). Metodologi Penelitian Kualitatif. Bandung: Remaja Rosda Karya.

Maulana, Achmad. (2004). Kamus Ilmiah Populer Lengkap, dengan EYD dan Pembentukan Istilah Serta Akronim Bahasa Indonesia. Yogyakarta: Absolut.

Nasution, S. (2006). Asas-asas Kurikulum.Jakarta:Bumiaksara.

Nasution, S. (2006). Kurikulum dan Pengajaran. Jakarta: Bumi Aksara.

Nurhadi \& Agung Setiawan. (2017). Model Penerapan Kerangka Kualifikasi Nasional Indonesia (KKNI) Sebagai Penguatan Mutu Program Studi Pendidikan Bahasa Arab. Al-Mahara Jurnal Pendidikan Bahasa Arab, 3(2), 219-238. Doi: https://doi.org/10.14421/almahara.2017.032-02 
Orlosky,Donald E. \&B. Othanel Slith. (1978). Curriculum Development, Issues and Insights. Chicago: $\mathrm{R}$ and Mc Nally College Publishing Company.

Soward, G. Wesley \& Mary-Margaret Scobey. (1968). The Changing Curriculum and the Elementary Teacher. California, Wadswoth Publishing Company.

Sukmadita, Nana Syaodih. (2004). Pengembangan Kurikulum, Teori dan Praktek. Bandung: Remaja Rosdakarya.

Sumardi, Muljanto. (1975). Pengajaran Bahasa Asing, Sebuah Tinjauan Dari Segi Metodologi.Jakarta: BulanBintang.

Syarifuddin. Dkk. (2013). Model Penerapan Kualifikasi Kurikulum Nasional Indonesia (KKNI) Sebagai Penguatan Mutu Program Studi Pariwisata Dan Pendidikan Bahasa Inggris Fakultas Sastra Dan Budaya Universitas Negeri Gorontalo. Gorontalo, Fak.Sastra dan Budaya Universitas Negeri Gorontalo.

Tafsir, Ahmad. (2004). Metodologi Pengajaran Agama Islam. Bandung: Remaja Rosdakarya.

Wahhab, Muhbib Abdul. (2016). Standarisasi Kurikulum Pendidikan Bahasa Arab Di Perguruan Tinggi Keagamaan Islam Negeri.Jurnal Arabiyat, Jurnal Pendidikan Bahasa Arab Dan Kebahasaaraban, 3 (1), 32-51. doi: 10.15408/a.v3i1.3187 